\title{
Do Managers Of Global Equity Funds Outperform Their Respective Style Benchmarks? Evidence From South Africa
}

\author{
Heng-Hsing Hsieh, PhD, CFA, University of the Western Cape, South Africa \\ Kathleen Hodnett, PhD, University of the Western Cape, South Africa \\ Paul van Rensburg, PhD, University of Cape Town, South Africa
}

\begin{abstract}
The results of our prior research on internationally-domiciled global equity funds suggest that active managers do not provide economic benefits, in addition to their underlying investment style benchmarks. This finding implies that the performances of global equity funds are derived mainly from the broad investment styles followed by the active managers rather than the stock-picking activities of the managers. We replicate our earlier research to investigate the performances of the six well-established global equity funds in the South African unit trust industry. Our results indicate that four out of the six South African fund managers under examination substantially underperform their passively-replicated style benchmarks. Our prior study results indicate that there is no significant difference between the performances of the internationally-domiciled global equity funds and their respective style benchmarks. By contrast, the stock-picking decisions of the South African fund managers are found to destroy value created by their respective style benchmarks in this study. Our findings suggest that investors who wish to follow particular investment styles would be better off by investing in exchange traded funds (ETF) that passively track the performances of their mandated investment styles in the global equity market with minimal costs.
\end{abstract}

Keywords: Style Analysis; Global Equity Funds; Return Decomposition; Active and Passive Portfolio Management; Value Investing; Momentum Investing; JSE; Unit Trusts; Mutual Funds

\section{INTRODUCTION}

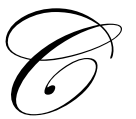

apital market anomalies such as the value effect, the size effect and the momentum effect documented in empirical research suggest that investment styles based on the discovered anomalies could provide additional sources of superior performance. This argument supports the use of active fund managers who follow distinctive investment styles to exploit the perceived market anomalies. Active fund managers are also entrusted by their clients for their insightful stock-picking within a pool of stocks with similar investment styles. The stock-picking decisions of active fund managers, however, do not gain support from empirical literature. Prior studies generally find that stock-picking decisions are ineffective and do not provide value, in addition to the value created by the fund's underlying asset classes and investment style benchmarks.

This study is an extension of the work of Hsieh and Hodnett (2011) who investigate the effectiveness of stock-picking decisions by the active managers of internationally-domiciled global equity funds. This paper undertakes to investigate the performances of the global equity funds managed by South African active fund managers. Following the return decomposition approach of Sharpe (1992), style benchmarks for the funds under examination are formed using the global momentum style portfolio, the global value style portfolio and the market proxy represented by the Morgan Stanley Capital International (MSCI) World Index. The fund return in excess of the style benchmark return is known as the selection return. The selection return represents the source of return attributable to the stock-picking decisions of the fund manager. Statistically significant selection return is an 
indication of the consistent outperformance or underperformance of the active fund manager compared to its style benchmark. By contrast, if the selection return appears to be random and insignificant, the fund return is primarily attributable to its style benchmark return and active stock-picking does not add value to the passively-replicated style benchmark for the fund.

This paper first discusses the prior literature on the merits of stock-picking by active fund managers from the international capital markets and the South African unit trust industry. The research database and sample section presents the database for the construction of global style portfolios and the characteristics of the South Africandomiciled global equity funds to be analyzed for this research. The methodology section provides a detailed discussion on the application of the return decomposition approach of Sharpe (1992) for this research. The empirical findings section analyzes the performances of the global equity funds managed by South African managers. The findings of the research are compared and contrasted to the results of prior research on the internationally-domiciled global equity funds. The summarized empirical findings and insights obtained from the analysis are presented in the conclusion section to provide recommendations on the global investment choices for investors who are interested in the opportunities offered by the global equity markets.

\section{REVIEW OF PRIOR LITERATURE}

Empirical studies that investigate the merits of stock picking activities generally conduct regression analysis on mutual fund returns to distinguish the portion of the mutual fund returns attributable to the manager's stock picking decision from the returns attributable to the asset allocation decision. When the returns on major asset classes are used to track the mutual fund returns in the regression analysis, the residuals of the regression represents the returns attributable to the manager's stock picking activities, or tracking error. On the other hand, the portion of the mutual fund returns that is successfully explained/tracked by the returns on the major asset classes represent the returns on a benchmark with similar investment exposures. The merits of active portfolio management through stock picking would gain support if the tracking error of the regression is statistically significant. By contrast, when the tracking error appears to be insignificant and the explanatory power of the benchmark return is high, the manager's stock picking decision is ineffective. The international evidence regarding performance attributions of U.S. mutual funds, hedge funds and internationally-domiciled global equity funds are provided in this section, followed by evidence from the South African unit trust industry.

\section{International Evidence}

Sharpe (1992) attempts to track the performance of U.S. mutual funds over the period from 1985 to 1989 using 12 asset classes and style indexes including U.S. Treasury indexes, fixed-income indexes, the value index, the growth index, small, medium and large cap indexes and European and Japanese stock indexes. Based on the return decomposition approach of Sharpe (1992), mutual fund returns are decomposed into asset allocation returns that are attributable to the explanatory power of the underlying asset classes, and the residual returns that are not explained by the asset class returns. The underlying asset classes and style indexes are found to significantly explain the returns of 395 mutual funds under analysis. Sharpe (1992) concludes that U.S. mutual fund returns are primarily driven by the asset allocation decision rather than the stock picking decisions of the managers. Based on the return decomposition approach of Sharpe (1992), the insignificant regression residuals are also evident in the study conducted by Ibbotson and Kaplan (2000) on U.S. balanced funds over the period from 1988 to 1998 and Vardharaj and Fabozzi (2007) on the U.S. and global equity funds over the period from 1995 to 2004.

When the performance attributions are extended to analyze hedge funds, Fung and Hsieh (1998) argue that the return decomposition approach of Sharpe (1992) is inappropriate in analyzing the return attributions of hedge funds that involve the use of short positions and derivatives. In order to capture the dynamics of the hedge fund returns, Fung and Hsieh (1998) include additional factors extracted via factor analysis. The samples included in their study include both mutual funds and hedge funds in the U.S. over the period from 1991 to 1995. The results show that the residuals of the regressions are statistically insignificant suggesting that active managers do not add value through stock picking. 
The performances of U.S. hedge funds are also studied by Baghai-Wadji and Klocker (2007) over the period from 1992 to 2004. Factors in addition to traditional asset classes are extracted using a neural network that categorizes hedge funds into style-consistent groups. Their results suggest that U.S. hedge fund managers, in general, do not add value beyond the performances of their respective style benchmarks over the examination period.

Hsieh and Hodnett (2011) investigate the performances of global equity funds over the period from 2002 to 2008. The Morgan Stanley Capital International (MSCI) World Index and three global investment style portfolios, namely the global size portfolio, the global momentum portfolio and the global value portfolio are used to track the performances of 12 internationally-domiciled global equity funds. The results show that the majority of the global equity fund returns are driven by their underlying style benchmark returns. The study shows little evidence that managers of global equity funds add value to the performance of their passively replicated style benchmarks through stock picking.

\section{The Unit Trust Industry in South Africa}

Collective investment schemes in South Africa generally take the form of unit trusts. The main difference between a unit trust and a mutual fund lies in their governance structure. While a unit trust is overseen by a trust company, it is the responsibility of the directors of a mutual fund company to ensure that the fund managers perform their duties according to the constituent documents. The unit trust industry in South Africa, which started as a single fund in 1965, provides investors with a professionally managed vehicle that offers sufficient diversification and liquidity across investments in different industries. Offshore investments were restricted for the South African unit trust industry until the deregulation of foreign investments in 1995, which significantly facilitates the diversity and range of products offered by the industry (Meyer-Pretorius and Wolmarans, 2006).

Collinet and Firer (2003) investigate the performance persistence of South African equity unit trusts over the period from 1980 to 1999 . Using a database that is free of survivorship bias, it is found that the past performances of South African unit trusts are only indications of their future performances for a period of 6 months or shorter. However, the study shows that buying the top performing funds over the past 6 months and rebalancing every 6 months would have outperformed the collective average returns of all unit trusts over the examination period after transaction costs are accounted for.

Yu (2008) analyzes the return attribution of South African unit trusts over the period from 2001 to 2006. The factors adapted by Yu (2008) include three local sector indices, namely, the JSE Resource Index (RESI), the JSE Industrial Index (INDI), the JSE Financial Index (FINI), and three style proxies, namely the momentum proxy, the large cap proxy and the value proxy. The results show that the sector and style proxies successfully track the performances of the South African unit trusts under examination, which leaves statistically insignificant residuals. These findings support the evidence that the stock picking decisions of South African active managers do not meaningfully contribute to their inherent investment style returns.

\section{RESEARCH DATABASE AND SAMPLE}

Following the methodology of Hsieh and Hodnett (2011), the style benchmarks used to track the performances of global equity funds are constructed from a market proxy and two global style portfolios, namely the global momentum portfolio and the global value portfolio. The market proxy is represented by the MSCI World Index while the style portfolios are constructed using the constituents of the Dow Jones (DJ) Sector Titans Composite.

\section{Research Database}

The DJ Sector Titans Composite Index is comprised of the largest 30 international stocks in each of the 19 sectors, which provides sufficient sector exposures in both developed and developing economies for this research. The 19 sectors covered by this database represent the second tier of the Industry Classification Benchmark (ICB). These sectors include automobiles and parts, banks, basic resources, chemicals, construction and materials, financial services, food and beverages, healthcare, industrial goods and services, insurance, media, oil and gas, personal and household goods, real estate, retail, technology, telecommunication, travel and leisure and utilities. 
As of 30 June 2010, the monthly total return index, stock price, number of outstanding stocks, market capitalization, book value per share, earnings per share, dividend per share, sales per share and cash flow per share of the 570 stocks comprising the DJ Sector Titans Composite Index, over the period from 01 January 1996 to 31 December 2008, are downloaded from DataStream International. The attribute values are subsequently converted into U.S. dollars.

Although the data obtained from DataStream International are not subject to look-ahead bias- since DataStream International only records data when they become available, the survivorship bias is nevertheless inherent in the database. The fact that only the largest stocks from each of the pre-specified industries are included in this research partially reduces the impact of survivorship bias as these stocks are likely to be survivors over time.

\section{Research Sample}

The global equity funds domiciled in the South African unit trust industry generally take the form of fund of funds (FOF) that holds a portfolio of global equity funds. There are in total 6 South African-domiciled global equity funds under analysis, namely ABSA International FOF, Allan Gray Orbis Global Equity FOF, Coronation International Active FOF, Investec Global Equity FOF, RMB International Equity FOF and Sanlam Global Equity Fund. With the exception of Sanlam Global Equity Fund, all funds under examination are FOF. The monthly U.S. dollar-denominated returns for the selected funds are downloaded from the database of Bloomberg Limited Partnership in the research office of Salient Quantitative Investment Management (Pty) Ltd.

The inception date, U.S. dollar-denominated fund value as of 30 June 2010 and the fund objectives extracted from Bloomberg are displayed in Table 1. As shown by the description section of Table 1, the selected funds generally place a cap on the investments in any particular fund at $20 \%$ of their asset values. The Investec Global Equity FOF is the fund with the longest listing history, which was registered immediately after the deregulation in 1995. The rest of the selected funds were registered after the late 1990s. The Allan Gray Orbis Global Equity FOF is the largest fund in terms of the U.S. dollar-denominated fund value of $\$ 771.40$ million.

\section{METHODOLOGY}

The global size, value and momentum investment style portfolios are constructed based on the monthly attributes of sample stocks at the beginning of each month over the period from 1 January 1996 to 31 December 2008. Following the portfolio construction methodology outlined in Hsieh and Hodnett (2011), the global size style portfolio is comprised of the top 100 stocks by U.S. dollar market capitalization at the beginning of each month over the examination period. The global value style portfolio, on the other hand, is constructed using the top 100 stocks with the highest average value of the five value matrices, namely book value-to-market ratio, earnings yield, dividend yield, sales-to-price ratio and cash flow-to-price ratio. With regard to the global momentum style portfolio, the top 100 stocks with the highest past 12-month returns computed from the total return indexes (inclusive of both capital gains and dividend yield) are selected for the portfolio.

Hsieh and Hodnett (2011) apply the return decomposition approach of Sharpe (1992) to track the performances of selected global equity funds using the MSCI World Index and the three style portfolios mentioned above as shown in Equation 1. The coefficients to the factors estimated by Equation 1 represent the style exposures of the fund under analysis to the returns on the MSCI World Index and the customized global style portfolios. The return on the style benchmark with the same exposures to the returns on the MSCI World Index and the style portfolios over the in-sample period is thus represented by the squared bracket of Equation 1. The error term of the regression $\varepsilon_{i, t}$ is the in-sample selection return of the fund that is not explained by its style benchmark. Thus, the selection return represents the deviation of the fund performance from its style benchmark, and the variance of the selection return is regarded as the fund's tracking error. 
Table 1: South African-Domiciled Global Equity Fund Descriptions

\begin{tabular}{|c|c|c|}
\hline Fund Name & Inception & Market Value \\
\hline 1. ABSA International FOF & $2001 / 01 / 9$ & \$10.52 Million \\
\hline
\end{tabular}

\begin{tabular}{|l||l||l|}
\hline 2. Allan Gray Orbis Global Equity FOF & $\mathbf{2 0 0 1 / 0 3 / 1 2}$ & \$771.40 Million
\end{tabular}

Allan Gray Orbis Global Equity Fund of Funds is a unit trust fund incorporated in South Africa. The Fund's central objective is to provide investors with the opportunity for offshore diversification, a hedge against Rand depreciation and superior returns on a foreign balanced portfolio versus the benchmark, at no greater risk of loss.

\begin{tabular}{|l|l|l|}
\hline 3. Coronation International Active FOF & $1997 / 08 / 01$ & \$105.26 Million
\end{tabular}

Coronation International Active Fund of Funds is a unit trust incorporated in South Africa. The objective of the Fund is to achieve long-term US-dollar based capital growth. The Fund invests in shares of international equity collective investment schemes. At least $85 \%$ of the Fund's assets will be invested internationally with no more than $20 \%$ with any one fund manager.

\begin{tabular}{|l||l||l|}
\hline 4. Investec Global Equity FOF & $\mathbf{1 9 9 6 / 0 1 / 0 5}$ & \$144.82 Million \\
\hline
\end{tabular}

Investec Global Equity Fund of Funds is a unit trust incorporated in South Africa. The objective of the Fund is to provide capital growth. The Fund invests primarily in high-quality international equities. The Fund may also invest up to $20 \%$ of its assets in other authorized funds.

\begin{tabular}{|l|l|l|}
\hline 5. RMB International Equity FOF & $\mathbf{1 9 9 9 / 4 / 2 8}$ & $\mathbf{\$ 3 2 . 8 2}$ Million \\
\hline
\end{tabular}

RMB International Equity Fund of Funds is a unit trust incorporated in South Africa. The aim of the Fund is to provide offshore diversification, a hedge against Rand depreciation, and steady capital growth. The Fund invests in offshore unit trusts excluding emerging markets. The Portfolio must hold a minimum of five unit trusts with no more than $20 \%$ in a one single investment.

\begin{tabular}{|c|c|c|}
\hline 6. Sanlam Global Equity Fund & $2002 / 08 / 03$ & \$141.88 Million \\
\hline
\end{tabular}

Sanlam Global Equity Fund is a unit trust incorporated in South Africa. The objective of the Fund is to provide superior returns in the medium to long term. The Fund invests in a well spread portfolio of equities across the globe.

Source: Bloomberg database as of 01 March 2010

$r_{i, t}=\left[\left(w_{i, M S C I} \times r_{M S C I, t}\right)+\left(w_{i, \text { Size }} \times r_{\text {Size,t }}\right)+\left(w_{i, \text { Mom }} \times r_{\text {Mom }, t}\right)+\left(w_{i, \text { Value }} \times r_{\text {Value }, t}\right)\right]+\varepsilon_{i, t}$

Where:

$r_{i, t}, r_{M S C l, t}, r_{\text {Size }, t}, r_{\text {Mom }, t}$ and $r_{\text {Value }, t}$

represent the returns on fund $i$, MSCI World Index, and the respective

$w_{i, M S C I}, w_{i, \text { Size }}, w_{i, M o m}$ and $w_{i, \text { Value }}$ global style proxies in month $t$; and represent fund $i$ 's style weights (exposures) for the MSCI World Index and the respective global style proxies.

The style exposures in Equation 1 is to be restricted between $0 \%$ and $100 \%$ to provide an indication of the passive mix of the fund's underlying investment styles without involvements in leverage and short-selling the underlying portfolios. In addition, the weighted least squares (WLS) technique is applied to place greater emphasis on more recent returns relative to more distant returns. Based on this technique, a series of rolling 36-month weighted least squares (WLS) regressions are performed monthly for each of the selected funds over the examination period starting from the earliest month for which the records of funds are available. The weight of 1.0 is first assigned to the fund return in the first month in the WLS regressions. The fund return in each month is allocated with a weight equivalent to $2^{1 / 36}$ times the weight assigned to its predecessor in the previous month. Thus, greater emphasis is placed on more recent returns relative to more distant returns. By minimizing the error term in the regressions, this procedure results in minimizng the fund's weighted tracking error.

Once the style weights of the selected global equity funds are estimated over the examination period, the out-of-sample style exposures in each month are estimated based on the in-sample style exposure estimates over the prior 36-month period using Equation 2. The out-of-sample style benchmark returns for the selected global equity funds are thus estimated as the sum of the products of the style exposures and the factors in Equation 2. 


$$
\tilde{r}_{i, \text { Style }, t}=\left(\tilde{w}_{i, M S C I, t} \times r_{\text {MSCI }, t}\right)+\left(\tilde{w}_{i, \text { Size }, t} \times r_{\text {Size }, t}\right)+\left(\tilde{w}_{i, \text { Mom }, t} \times r_{\text {Mom }, t}\right)+\left(\tilde{w_{i, \text { Value }, t}} \times r_{\text {Value }, t}\right)
$$

Where:

$\sim$

$r_{i, \text { Style }, t}$

represents the out-of-sample style benchmark return for fund $i$ in month $t$; and

$\tilde{w}_{i, M S C I, t}, \tilde{w}_{i, \text { Size,t }}, \tilde{w}_{i, \text { Mom }, t}$ and $\tilde{w}_{i, \text { Value }, t}$

represent the respective out-of-sample style exposure estimates for fund $i$ in month $t$ computed using return data from month $t-36$ through month $t-1$ based on Equation 1.

The monthly out-of-sample selection return is computed as the fund's actual return in excess of the out-ofsample style benchmark return as shown in Equation 3:

$\tilde{\varepsilon}_{i, t}=r_{i, t}-\tilde{r}_{i, \text { Style }, t}$

The average out-of-sample style benchmark return and the selection return for each of the selected funds are computed. The statistical significance of the time-series selection return calculated in Equation 3 represents the contribution of the manager's stock picking activities, in addition to the returns produced by the style benchmark. Whether the stock picking decisions of South African managers contribute positively to the fund performance on a risk-adjusted basis is subsequently evaluated using the Sharpe ratio as shown in Equation 4.

Sharpe Ratio $_{P}=\frac{R_{P}-R_{f}}{\sigma_{P}}$

Where:

$R_{P} \quad$ is the return on portfolio $P$ over the evaluation period;

$\sigma_{P} \quad$ is the standard deviation of portfolio $P$ 's return over the evaluation period; and

$R_{f} \quad$ is the risk-free proxy (U.S. 3-month Treasury yield is employed for this purpose).

Following the methodology of Hsieh and Hodnett (2011), the style risk-adjusted return of the global equity funds are estimated using Equation 5 by regressing the out-of-sample fund returns on the out-of-sample style benchmark returns. The explanatory power of the regression provides an indication as to the ability of the customized style benchmark in tracking the performances of the selected funds.

$r_{i, t}=\alpha_{i}+b_{i, \text { Style }} \times \tilde{r}_{i, \text { Style }, t}+e_{i, t}$

Where:

$\alpha_{i} \quad$ is the regression constant that is not explained by fund $i$ 's style risk;

$b_{i, \text { Style }}$ is the sensitivity of fund $i$ 's return to movements in the style benchmark return; and

$e_{i, t} \quad$ is the random error of the regression that is not explained by the style benchmark.

\section{EMPIRICAL FINDINGS}

The style analysis of the global equity funds are summarized in Table 2. The out-of-sample average fund returns, standard deviations and Sharpe ratios are presented under the section "Performance Characteristics". Under the section "Performance Attribution", the average out-of-sample fund return is decomposed into (1) average style benchmark return and (2) average selection return over the evaluation period. The average style benchmark return is estimated by Equation 2. The average selection return is the difference between the actual fund return and the average style benchmark return as estimated by Equation 3 . 
Although all of the funds under examination are in existence for 5 years or longer, the evaluation periods are shortened due to the lack of earlier data for certain funds. In addition, the first 36 months of the available data are used as the first in-sample period. The statistical significance regarding the average fund returns, the average style benchmark returns, the average selection returns and regression coefficients are indicated by their $t$-statistics shown in parentheses. Statistical significant values at a 5\% interval are highlighted in bold.

The time-series style exposures of the selected funds are illustrated in Appendix A. Referring to Appendix A, the periodic exposures to the return on the MSCI World Index are indicated by the white-shaded area; the periodic exposures to the return on the global size portfolio are indicated by the brick-shaded area; the periodic exposures to the return on the global momentum portfolio are indicated by the black-shaded area; and the periodic exposures to the return on the global value portfolio are indicated by the grey-shaded area.

Table 2 Return Attribution of Global Equity Funds

\begin{tabular}{|c|c|c|c|c|c|c|}
\hline $\begin{array}{l}\text { Fund Inception: } \\
\text { Evaluation: }\end{array}$ & $\begin{array}{l}\text { ABSA } \\
\text { International } \\
\text { FOF } \\
1 / 9 / 2001 \\
2006-2008\end{array}$ & $\begin{array}{l}\text { Allan Gray } \\
\text { Orbis Global } \\
\text { Equity FOF } \\
3 / 12 / 2001 \\
2007-2008\end{array}$ & $\begin{array}{l}\text { Coronation } \\
\text { International } \\
\text { Active FOF } \\
8 / 1 / 1997 \\
2002-2008\end{array}$ & $\begin{array}{l}\text { Investec } \\
\text { Global Equity } \\
\text { FOF } \\
1 / 5 / 1996 \\
2002-2008\end{array}$ & $\begin{array}{l}\text { RMB } \\
\text { International } \\
\text { Equity } \\
\text { FOF } \\
28 / 4 / 1999 \\
2002-2008 \\
\end{array}$ & $\begin{array}{l}\text { Sanlam } \\
\text { Global Equity } \\
\text { Fund } \\
8 / 3 / 2002 \\
2005-2008\end{array}$ \\
\hline \multicolumn{7}{|l|}{$\begin{array}{l}\text { Performance } \\
\text { Characteristics }\end{array}$} \\
\hline$\overline{\text { Avg. Fund Return }}$ & $\begin{array}{l}-1.05 \% \\
{[-1.189]}\end{array}$ & $\begin{array}{l}-3.34 \% \\
{[-2.017]}\end{array}$ & $\begin{array}{l}1.24 \% \\
{[3.505]}\end{array}$ & $\begin{array}{l}0.46 \% \\
{[0.836]}\end{array}$ & $\begin{array}{l}0.14 \% \\
{[0.218]}\end{array}$ & $\begin{array}{l}-0.59 \% \\
{[-0.708]}\end{array}$ \\
\hline $\begin{array}{l}\text { Std. Deviation } \\
\text { Sharpe Ratio }\end{array}$ & $\begin{array}{l}5.22 \% \\
-0.257\end{array}$ & $\begin{array}{l}6.19 \% \\
-0.561\end{array}$ & $\begin{array}{l}3.09 \% \\
0.332\end{array}$ & $\begin{array}{l}4.79 \% \\
0.050\end{array}$ & $\begin{array}{l}5.68 \% \\
-0.014\end{array}$ & $\begin{array}{l}5.59 \% \\
-0.158\end{array}$ \\
\hline \multicolumn{7}{|l|}{ Return Attribution } \\
\hline $\begin{array}{l}\text { (1) Avg. Style } \\
\text { Return }\end{array}$ & $\begin{array}{l}-0.21 \% \\
{[-0.226]}\end{array}$ & $\begin{array}{l}-3.67 \% \\
{[-1.648]}\end{array}$ & $\begin{array}{l}0.71 \% \\
{[1.170]}\end{array}$ & $\begin{array}{l}0.84 \% \\
{[1.372]}\end{array}$ & $\begin{array}{l}0.62 \% \\
{[1.031]}\end{array}$ & $\begin{array}{l}0.41 \% \\
{[0.459]}\end{array}$ \\
\hline $\begin{array}{l}\text { Std. Deviation } \\
\text { Sharpe Ratio }\end{array}$ & $\begin{array}{l}5.62 \% \\
-0.090\end{array}$ & $\begin{array}{l}8.34 \% \\
-0.457\end{array}$ & $\begin{array}{l}5.42 \% \\
0.091\end{array}$ & $\begin{array}{l}5.32 \% \\
0.116\end{array}$ & $\begin{array}{l}5.41 \% \\
0.075\end{array}$ & $\begin{array}{l}6.06 \% \\
0.020\end{array}$ \\
\hline $\begin{array}{l}\text { (2) Avg. Selection } \\
\text { Return }\end{array}$ & $\begin{array}{l}-0.83 \% \\
{[-1.792]}\end{array}$ & $\begin{array}{l}0.33 \% \\
{[0.377]}\end{array}$ & $\begin{array}{l}0.53 \% \\
{[1.135]}\end{array}$ & $\begin{array}{l}-0.38 \% \\
{[-1.653]}\end{array}$ & $\begin{array}{l}-0.49 \% \\
{[-1.257]}\end{array}$ & $\begin{array}{l}-1.00 \% \\
{[-2.758]}\end{array}$ \\
\hline Std. Deviation & $2.75 \%$ & $3.32 \%$ & $4.19 \%$ & $2.00 \%$ & $3.45 \%$ & $2.44 \%$ \\
\hline \multicolumn{7}{|l|}{$\underline{\text { Style Replication }}$} \\
\hline R-Squared & $76.30 \%$ & $87.98 \%$ & $40.73 \%$ & $86.01 \%$ & $65.18 \%$ & $83.72 \%$ \\
\hline Intercept & $\begin{array}{l}-0.009 \\
{[-2.004]}\end{array}$ & $\begin{array}{l}-0.008 \\
{[-1.189]}\end{array}$ & $\begin{array}{l}0.010 \\
{[3.645]}\end{array}$ & $\begin{array}{l}-0.002 \\
{[-1.145]}\end{array}$ & $\begin{array}{l}-0.004 \\
{[-1.028]}\end{array}$ & $\begin{array}{l}-0.009 \\
{[-2.758]}\end{array}$ \\
\hline Slope Coefficient & $\begin{array}{l}\mathbf{0 . 8 1 1} \\
{[10.307]}\end{array}$ & $\begin{array}{l}\mathbf{0 . 6 9 7} \\
{[9.373]}\end{array}$ & $\begin{array}{l}0.363 \\
{[7.321]}\end{array}$ & $\begin{array}{l}0.835 \\
{[21.329]}\end{array}$ & $\begin{array}{l}0.848 \\
{[12.083]}\end{array}$ & $\begin{array}{l}0.845 \\
{[14.872]}\end{array}$ \\
\hline
\end{tabular}

\section{Performance Evaluation}

An examination of the average fund returns of the South African-domiciled global equity funds reveals that 3 out of 6 funds earn negative returns over their respective evaluation periods (refer to Table 2). When the fund performances are evaluated on a risk-adjusted basis, 4 out of 6 funds have negative Sharpe ratios over their respective evaluation periods. The poor performances of the ABSA International FOF and the Allan Gray Orbis Global Equity FOF are partially attributable to the fact that the financial market crisis of 2008 is covered by their 
respective short evaluation periods. The Coronation International Active FOF is the only fund that has significant average returns over the evaluation periods. The standard deviation of returns for the Coronation International Active FOF is also the lowest amongst all 6 funds under examination.

The analysis of the performance attributions of the selected funds involves the analysis of their return attributions in terms of style benchmark returns and the selection returns, and the degree to which the style benchmark returns track the actual fund returns. Thus, the analysis of the performance attributions provide indications as to whether the underlying investment styles of the funds are replicated successfully by the style benchmarks, and whether the fund managers are able to outperform their corresponding style benchmarks in a consistent manner through the managers' superior stock selection skills. When the actual fund return is higher than the style benchmark return, the resulting positive selection return is an indication of the manager's skill. By contrast, when the selection return is negative, the fund underperforms the style benchmark due to the manager's poor alternative stock selections compared to the style benchmark.

With the exception of the Allan Gray Orbis Global Equity FOF and the Coronation International Active FOF, the South African-domiciled global equity funds yield lower average returns than their respective style benchmarks due to their poor alternative stock allocations. The worst selection return is detected for the Sanlam Global Equity Fund with significant negative average monthly selection return of $-1 \%$. The poor stock-picking skills of the fund manager have severely dragged down the overall fund performance over the evaluation periods. In addition, no significant positive selection returns are detected for any of the global equity funds. These findings question the validity of the alternative stock allocations of the South African fund managers in creating value, in addition to what is already provided by their style benchmarks.

However, the performance of the fund managers cannot be totally negated. The standard deviations of the selected South African-based global equity funds are lower than the standard deviations of their respective style benchmarks, with the exception of the RMB International Equity FOF, which reflects the skill and the effort of the fund managers in minimizing the volatility of their fund values. Comparing the Sharpe ratios of the South Africanbased global equity funds to their style benchmarks reveals that the Coronation International Active FOF is the only fund that has outperformed its style benchmark in terms of the Sharpe ratio ( 0.332 for the fund versus 0.091 for the style benchmark). Although the style benchmark returns seem to be more volatile than the fund returns, the style benchmarks still manage to deliver higher risk-adjusted performances compared to their corresponding South African-based global equity funds.

The slope coefficient of the style-based regression measures the sensitivity of the fund return to movements in the style benchmark returns. The slope coefficients for all selected funds are significantly positive, indicating that the style benchmarks are appropriate in modeling the funds' respective underlying investment styles. The high $R$ squared of the regressions indicate that the predicted style benchmark returns are able to explain a large proportion of the out-of-sample actual fund returns. The regression intercept represents the fixed monthly deviation of the fund return from the style benchmark return as opposed to the monthly random deviation reflected in the regression residuals. Thus, the regression intercept represents the style risk-adjusted excess return of the funds under analysis. The $t$-statistics of the intercepts, for the majority of the funds, appear to be negative, but insignificant, except for the significant positive intercept of the Coronation International Active FOF and the significant negative intercept of the Sanlam Global Equity Fund. The consistent style risk-adjusted excess return earned by the Coronation International Active FOF is in direct contrast to the consistent underperformance of the Sanlam Global Equity Fund over their respective evaluation periods.

\section{Time-Series Style Exposure Analysis}

The ABSA International FOF and the Allan Gray Orbis Global Equity FOF do not have exposures to the global size investment style portfolio (refer to Appendix A1 and Appendix A2 respectively). The ABSA International FOF is found to have the most frequent rotation between the value and momentum investment styles, among the selected funds, throughout the evaluation period from 1 February 2006 to 31 December 2008. The strategy of the Allan Gray Orbis Global Equity FOF is dominated by the value investment style over the evaluation period. Unlike the Allan Gray Orbis Global Equity FOF and the ABSA International Equity FOF, the rest of the 
selected South African-domiciled global equity funds tilt their investment strategies towards the momentum investment style after 2006. The global momentum portfolio alone serves as the style benchmark for the Coronation International Active FOF, the Investec Global Equity FOF, the RMB International Equity FOF and the Sanlam Global Equity Fund since 2006 (refer to Appendix A3 through Appendix A6). The style rotations for the Investec Global Equity FOF (refer to Appendix A4) and the RMB International Equity FOF (refer to Appendix A5) are similar in that their style compositions are dominated and shared by the MSCI World Index and the global size portfolio prior to 2005. On the other hand, the return of the Coronation International Active FOF (refer to Appendix A3) is mainly attributable to the return on the global size portfolio prior to 2006.

Regardless of the role of the global size proxy in modelling the style returns of the South African-domiciled global equity funds, the observation that the South African-based global equity funds allocate their investments mainly to the passive global size proxy and the MSCI World Index prior to 2006, as opposed to their momentumoriented investment style after 2006, is a reflection of the shifts in the objectives of the South African-domiciled global equity funds from diversification focus to performance delivery.

\section{CONCLUSION}

In this paper style benchmarks are constructed for 6 actively-managed global equity funds domiciled in South Africa. The benchmarks, representing the underlying investment styles of the selected global equity funds, are constructed by allocating capital to the MSCI World Index, the global size portfolio, the global value portfolio and the global momentum portfolio. Adopting the style-decomposition approach of Sharpe (1992), the style benchmarks estimate monthly style exposures of the selected funds using WLS regressions. The performances of the South African-domiciled global equity funds are subsequently evaluated against the performances of their respective style benchmarks.

The majority of the South African-based global equity funds are collective portfolios of other funds. This branch of collective investment scheme is known as fund of funds (FOF). Among the 6 selected South Africanbased global equity funds, the Allan Gray Orbis Global Equity FOF and the Coronation International Active FOF are the only funds that manage to create value above what is offered by their style benchmark. The Coronation International Active FOF is the only fund that yields significant style risk-adjusted excess returns. The rest of the South African-based global equity funds do not deliver value, in addition to the value provided by their respective style benchmarks in absolute terms and in style risk-adjusted terms. The Sanlam Global Equity FOF appears to be the worst performer with significant negative style risk-adjusted excess return and significant negative average selection return, which severely drags down the fund performance.

Although it can be argued that the fund managers' efforts in controlling risk are reflected in the lower standard deviations of the funds compared to the standard deviations of their respective style benchmark, the Coronation International Active FOF is the only South African-based global equity fund that beats its benchmark in terms of the Sharpe Ratio. Comparing this result to the results of Hsieh and Hodnett (2011) on the internationallydomiciled global equity funds, international fund managers are better in delivering added value compared to the South African fund managers.

The analysis of the style exposures of the funds reveals that most of the South African-domiciled global equity funds pursue aggressive momentum-oriented investment strategies after 2006. Prior to 2006, most of the funds undertake a broad-based equity investment style with exposures mainly in the MSCI World Index and the global size portfolio. This observation reflects the shift in the objectives of South African-based funds from diversification focus to performance delivery.

In conclusion, the passive replications of the underlying investment styles of the selected global equity funds, based on the Sharpe (1992) style decomposition approach, are successful with high $R$-squared. With limited contribution from the selection return to the actual fund return, the performance of the style benchmark serves as an unbiased estimate of the performance of the fund being replicated. Although there is no clear evidence that the managers of the global equity funds are able to outperform their respective style benchmarks in terms of the style risk-adjusted excess return and the Sharpe ratio, the internationally-domiciled global equity funds, in general, 
demonstrate a better ability in creating value in addition to the style benchmark returns, compared to the South African-based global equity funds. This finding suggests that South African investors who wish to follow particular investment styles would be better off by investing in exchange traded funds (ETF) that passively track the performances of their mandated investment styles in the global equity market with minimal costs.

\section{ACKNOWLEDGEMENT}

This work is supported by the National Research Foundation (NRF) of South Africa. We wish to thank the research office of the University of the Western Cape for their support.

\section{AUTHOR INFORMATION}

Dr. Heng-Hsing Hsieh, CFA is the Head of Finance in the School of Business and Finance at the University of the Western Cape, South Africa. He is a CFA charterholder and a member of the South African Institute of Financial Markets (SAIFM). E-mail: ahsieh@uwc.ac.za. Corresponding Author.

Dr. Kathleen Hodnett is currently a Research Fellow (funded by the National Research Foundation (NRF) of South Africa) in the School of Business and Finance at the University of the Western Cape, South Africa. She is a member of the International Institute of Forecasters (IIF) and an associate member of the South African Institute of Financial Markets (SAIFM).

Prof. Paul van Rensburg is the Frank Robb Professor of Finance at the University of Cape Town, South Africa. He is the principal of Salient Quantitative Investment Management. E-mail: paul.vanrensburg@uct.ac.za.

\section{REFERENCES}

1. Baghai-Wadji R and Klocker S (2007), "Performance and Style Shifts in the Hedge Fund Industry", London Business School, Working Paper, 1-48.

2. Banz R W (1981), "The Relationship between Return and Market Value of Common Stocks", Journal of Financial Economics, no 9, 3-18.

3. Basu S (1977), "The Investment Performance of Common Stocks in Relation to Their Price to Earnings Ratio: A Test of the Efficient Markets Hypothesis", Journal of Finance, vol 32, no 3, 663-682.

4. Brown P, Kleidon A W and Marsh T A (1983), "New Evidence on the Nature of Size-Related Anomalies in Stock Prices", Journal of Financial Economics, no 12, 33-56.

5. Carhart M (1997), "On Persistence of Mutual Fund Performance", Journal of Finance, no 52, 57-82.

6. Chan K C, Hameed A and Tong W (2000), "Profitability of Momentum Strategies in the International Equity Markets", The Journal Financial and Quantitative Analysis, vol 35, no 2, 153-172.

7. Chan L K C and Lakonishok J (2004), "Value and Growth Investing: Review and Update", Financial Analysts Journal, vol 60, no 1, 71-86.

8. Collinet L and Firer C (2003), "Characterizing Persistence of Performance Amongst South African General Equity Unit Trusts", Omega, vol 31, no 6, 523-538.

9. Fama E F and French K R (1992), "The Cross-Section of Expected Stock Returns", Journal of Finance, vol 47, 427-465.

10. Fama E F and French K R (1993), "Common Risk Factors in the Returns on Stocks and Bonds", Journal of Financial Economics, vol 33 no 1, 3-56.

11. Fama E F and French K R (1998), "Value Versus Growth: The International Evidence", Journal of Finance, vol 53, no 6, 1975-1999.

12. Forner C and Marhuenda J (2003), "Contrarian and Momentum Strategies in the Spanish Stock Market Seasonality", Journal of Finance, vol 42, no 3, 557-581.

13. Fung W and Hsieh D A (1998), "Performance Attribution and Style Analysis: From Mutual Funds to Hedge Funds", Paradigm Financial Products, Principal Publisher.

14. Hsieh H. and Hodnett K (2011), "Do Managers of Global Equity Funds Outperform Their Respective Style Benchmarks? An Empirical Investigation", International Business and Economics Research Journal, vol 10 , no $12,1-10$. 
15. Ibbotson R D and Kaplan P (2000), "Does Asset Allocation Policy Explain 40, 90, or 100 Percent of Performance?", Financial Analysts Journal, vol 56, no 1, 26-33.

16. Jegadeesh N and Titman S (March 1993), "Returns to Buying Winners and Selling Losers: Implications for Stock Market Efficiency", Journal of Finance, vol 48, no 1, 65-91.

17. Meyer-Pretorius M C and Wolmarans H P (2006), "The Unit Trust Industry in South Africa from 1965 to June 2005: Are Investors Better Off?”, Meditari Accountancy Research, vol 14, no 1, 49-67.

18. Reinganum M R (1981), "Misspecification of Capital Asset Pricing - Empirical Anomalies Based on Earnings' Yields and Market Values", Journal of Financial Economics, no 9, 19-46.

19. Reinganum M R (1983), "The Anomalous Stock Market Behavior of Small Firms in January - Empirical Tests for Tax-Loss Selling Effects", Journal of Financial Economics, no 12, 89-104.

20. Schiereck D, De Bondt W F M and Weber M (1999), "Contrarian and Momentum Strategies in Germany", Financial Analysts Journal, vol 55, no 6, 104-116.

21. Sharpe W F (1992), “Asset Allocation: Management Style and Performance Measurement”, Journal of Portfolio Management, vol 18, 7-19.

22. Vardharaj R and Fabozzi F J (2007), "Sector, Style, Region: Explaining Stock Allocation Performance", Financial Analysts Journal, vol 63, no 3, 59-70.

23. Yu X (2008), "Style Indices and Active Portfolio Construction on the JSE", University of Cape Town, Working Paper. 


\section{APPENDIX A Style Exposures (Weights) of the Global Equity Funds}

The appendix contains information regarding the exposures of the selected funds to movements in the MSCI World Index and the customized global size, momentum and value investment style portfolios. The periodic exposures to the return on the MSCI World Index are indicated by the white-shaded area; the periodic exposures to the return on the global size portfolio are indicated by the brick-shaded area; the periodic exposures to the return on the global momentum portfolio are indicated by the black-shaded area; and the periodic exposures to the return on the global value portfolio are indicated by the grey-shaded area.

APPENDIX A.1

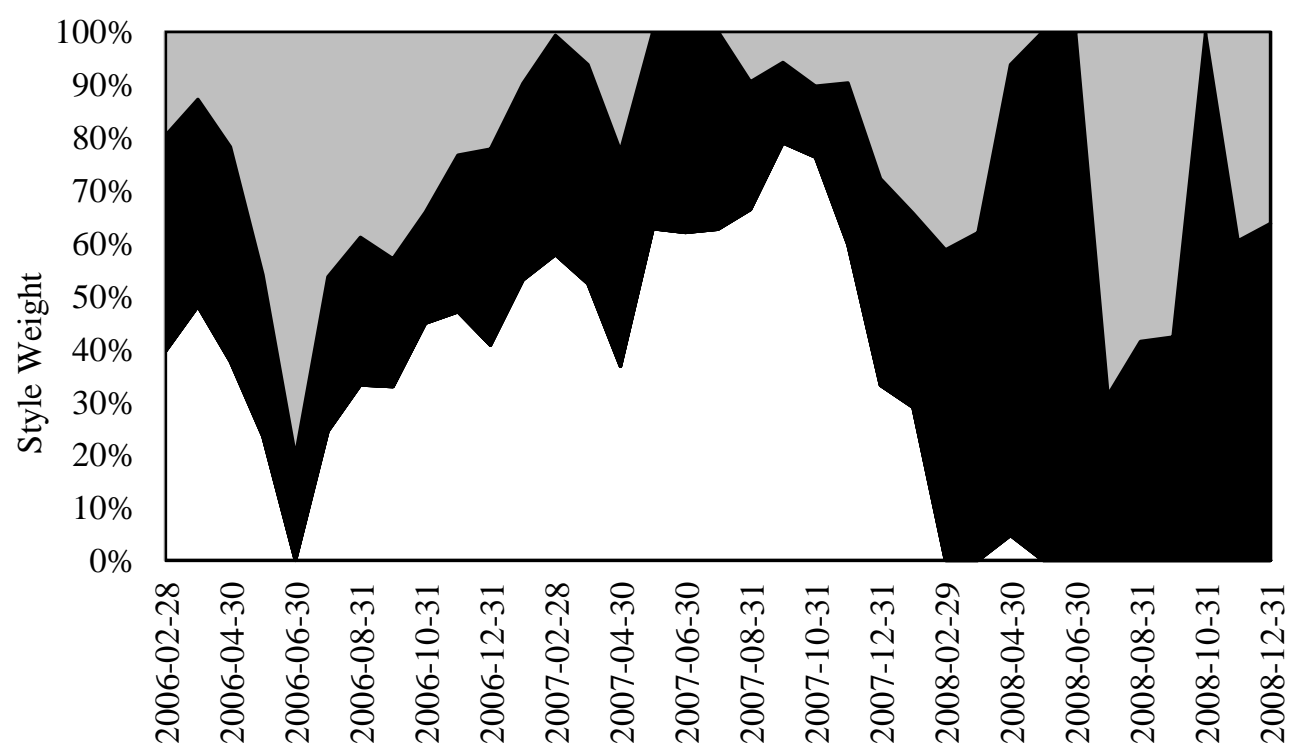

ABSA International FOF (2006 to 2008)
APPENDIX A.2

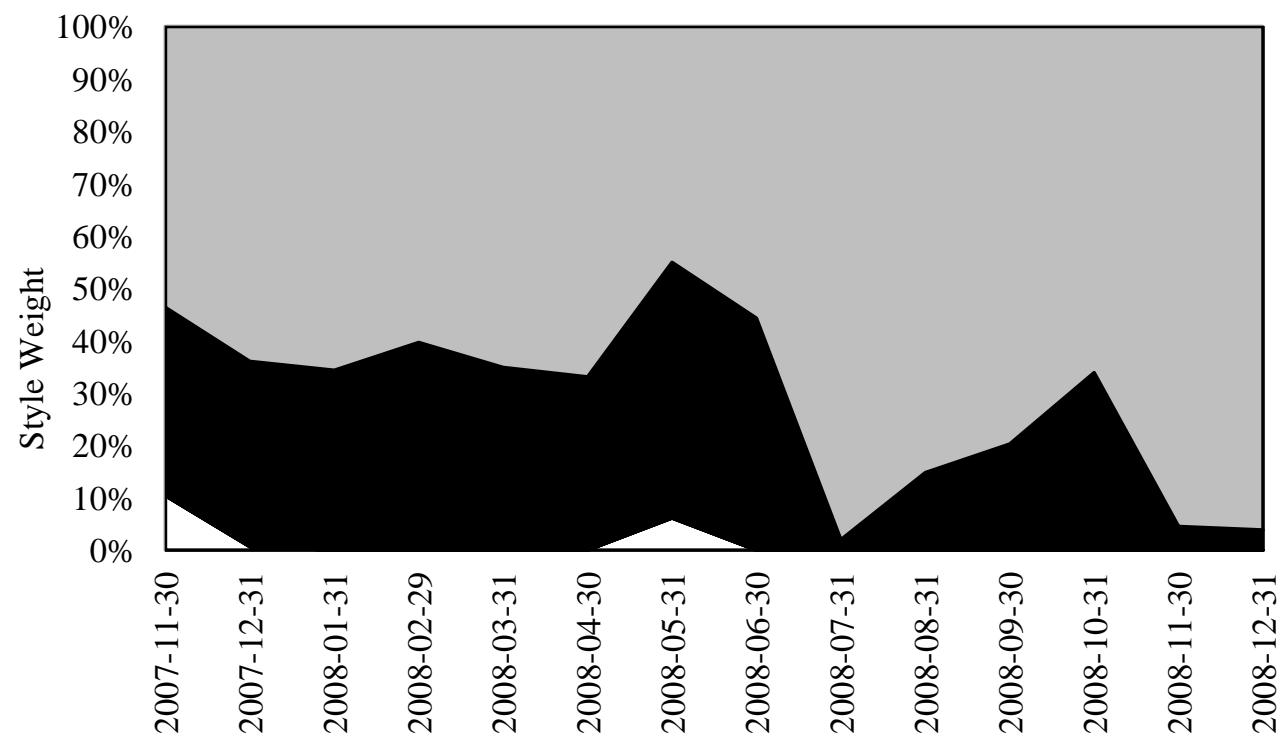

Allan Gray Orbis Global Equity FOF (2007 to 2008)

C 2012 The Clute Institute 


\section{APPENDIX A Style Exposures (Weights) of the Global Equity Funds - Continued}

The appendix contains information regarding the exposures of the selected funds to movements in the MSCI World Index and the customized global size, momentum and value investment style portfolios. The periodic exposures to the return on the MSCI World Index are indicated by the white-shaded area; the periodic exposures to the return on the global size portfolio are indicated by the brick-shaded area; the periodic exposures to the return on the global momentum portfolio are indicated by the black- shaded area; and the periodic exposures to the return on the global value portfolio are indicated by the grey-shaded area.

APPENDIX A.3

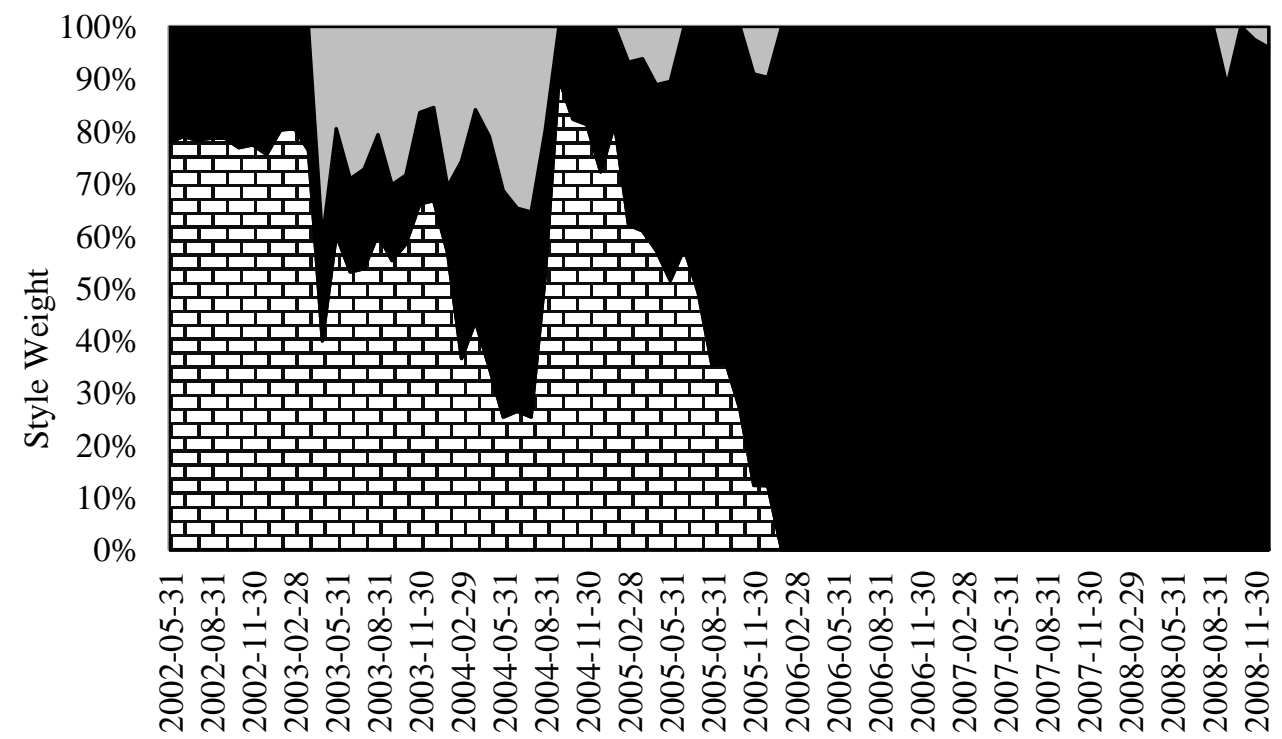

APPENDIX A.4

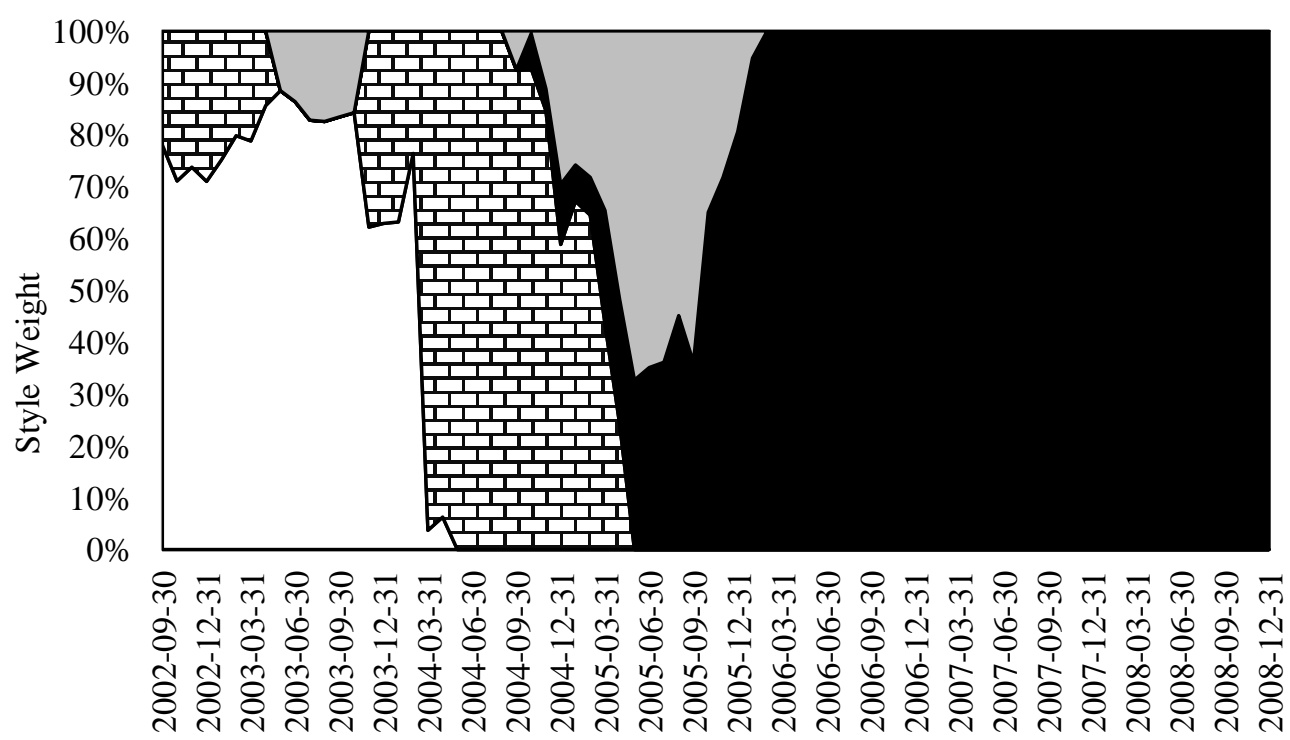




\section{APPENDIX A Style Exposures (Weights) of the Global Equity Funds - Continued}

The appendix contains information regarding the exposures of the selected funds to movements in the MSCI World Index and the customized global size, momentum and value investment style portfolios. The periodic exposures to the return on the MSCI World Index are indicated by the white-shaded area; the periodic exposures to the return on the global size portfolio are indicated by the brick-shaded area; the periodic exposures to the return on the global momentum portfolio are indicated by the black- shaded area; and the periodic exposures to the return on the global value portfolio are indicated by the grey-shaded area.

APPENDIX A.5

RMB International Equity FOF (2002 to 2008)

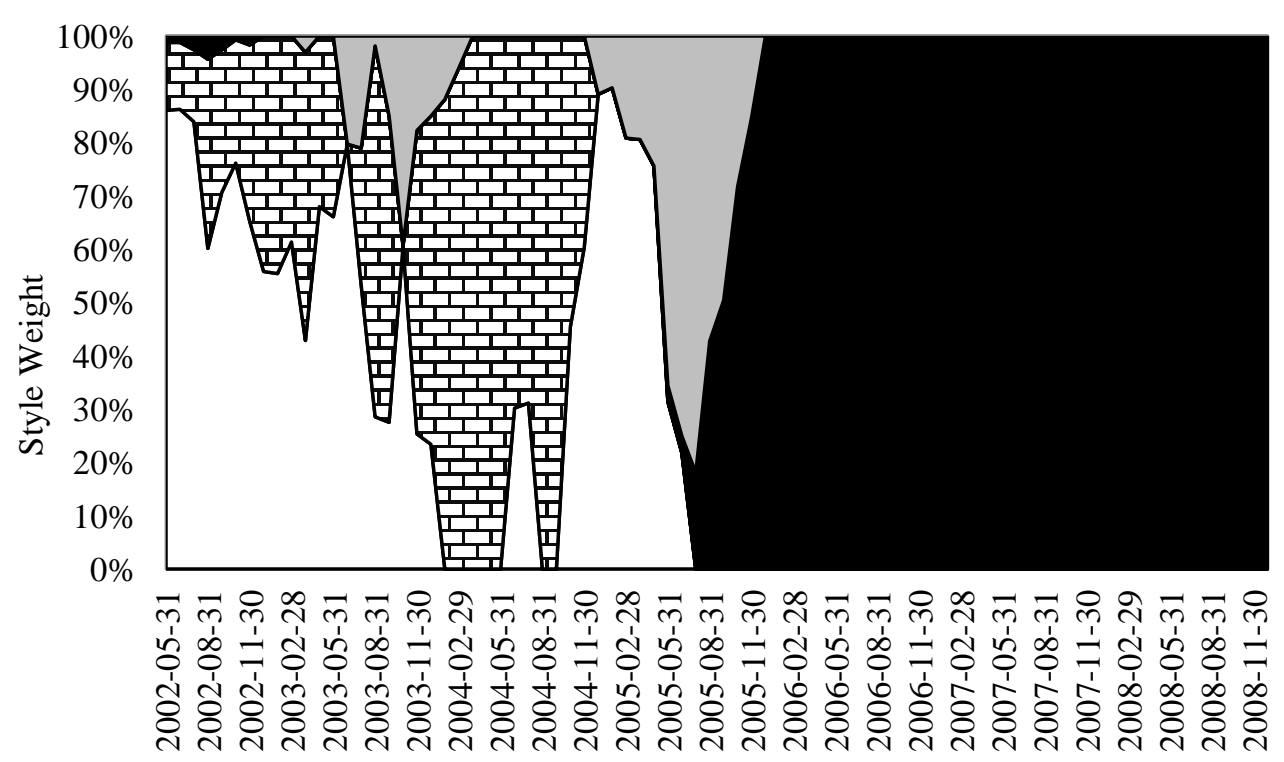

APPENDIX A.6

Salam Global Equity Fund (2005 to 2008)

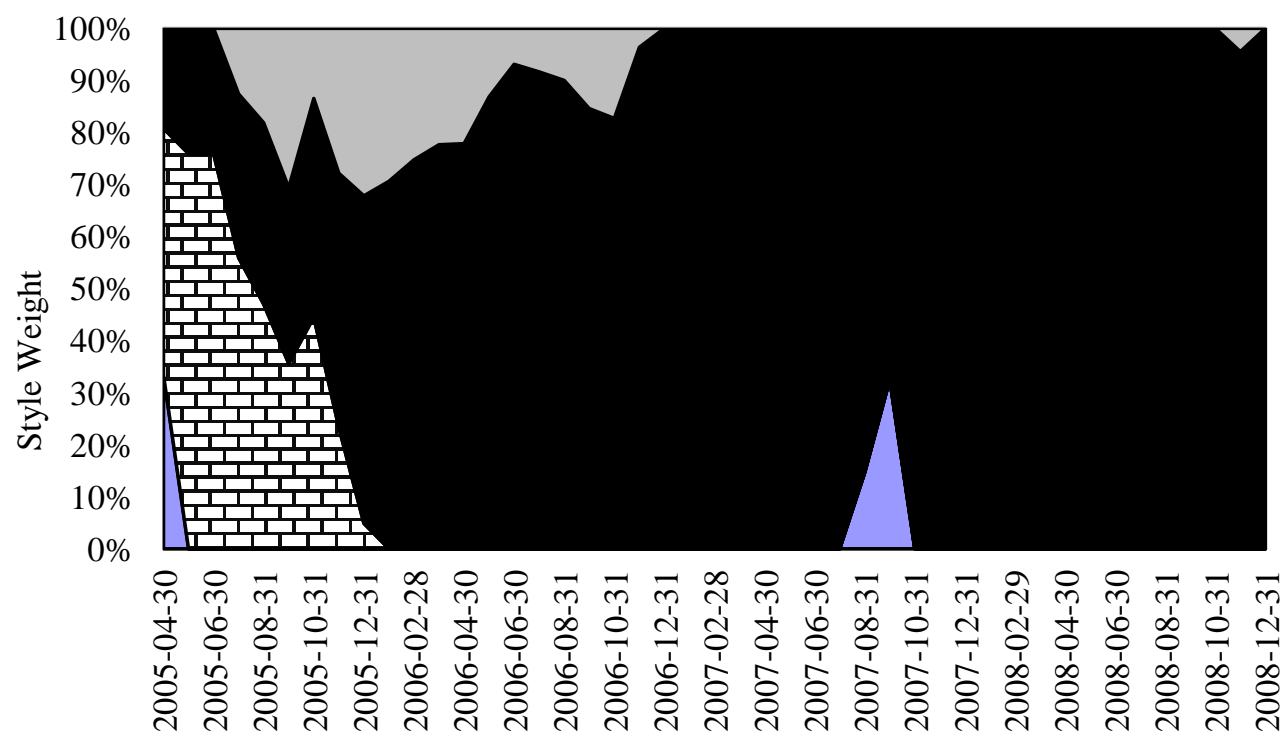

